Jurnal PG-PAUD Trunojoyo: Jurnal Pendidikan dan Pembelajaran Anak Usia Dini, Volume 8, Nomor 2, Oktober 2021, hal 74-86, ISSN: 2528-3553 (online), ISSN: 2407-4454 (print)

\title{
PERAN METODE BERCERITA TERHADAP PERKEMBANGAN BAHASA ANAK USIA DINI
}

\author{
Sri Hartati ${ }^{1}$ \\ Eka Damayanti² \\ M. Rusdi T ${ }^{3}$ \\ Dahlia Patiung ${ }^{4}$ \\ 1.2.3,4Programstudi PIAUD, UIN Alauddin Makassar \\ Email: srihartati280898@gmail.com, eka.damayanti@uin-alauddin.ac.id, rusdithahir@gmail.com. \\ dahlia.patiung@uin-alauddin.ac.id
}

Received (July), Accepted (September), Published (October)

\begin{abstract}
The Role of Storytelling Methods for Early Childhood Language Development. Language development is one of the most important aspects stimulated in early childhood. This study aimed to explain the role of storytelling methods towards early childhood language development. This research used the library study method. The data sources used are 11 journals that match the research focus criteria. Data analysis techniques using descriptive analysis of the Miles \&Huberman model. The results illustrate the method of storytelling can improve the development of early childhood language, especially speech ability. The improvement was obtained because of the presentation of storytelling methods using colorful book media so that it is fun and fun and train the ability to speak with the courage to appear to tell stories in front of the class. Storytelling method is also interesting because it uses hand puppet media, power point media and audiovisual media. Storytelling methods can also improve children's listening and vocabulary skills by using various themes, simple sentences and easy to understand by the child. The implication in this study is that storytelling methods play a role in early childhood language development. Therefore, it is expected for educators to use a variety of creative and innovative methods in helping the learning process so that learning objectives can be achieved properly, in addition to creating a happy atmosphere and not quickly boring for children while learning.
\end{abstract}

Keywords: early childhood, language development, storytelling methods

Abstrak: Peran Metode Bercerita terhadap Perkembangan Bahasa Anak Usia Dini. Perkembangan bahasa merupakan salah satu aspek yang sangat penting distimulasi pada anak usia dini. Penelitian ini bertujuan untuk memaparkan peran metode bercerita terhadap perkembangan bahasa anak usia dini. Penelitian ini menggunakan metode studi pustaka. Sumber data yang digunakan berupa 11 jurnal yang sesuai dengan kriteria fokus penelitian. Teknik analisis data menggunakan analisis deskriptif model Miles \& Huberman. Hasil penelitian menggambarkan metode bercerita dapat meningkatkan perkembangan bahasa anak usia dini khususnya kemampuan bicara. Peningkatan tersebut diperoleh karena penyajian metode bercerita menggunakan media buku yang berwarna-warni sehingga menyenangkan dan mengasyikan serta melatih kemampuan bicara dengan keberanian tampil bercerita di depan kelas. Metode bercerita juga menarik karena menggunakan media boneka tangan, media power point dan media audiovisual. Metode bercerita juga dapat meningkatkan kemampuan menyimak dan kemampuan kosakata anak dengan menggunakan tema yang beragam, kalimat yang sederhana dan mudah dipahami oleh anak. Implikasi dalam penelitian ini adalah metode bercerita berperan terhadap perkembangan bahasa anak usia dini. Oleh karena itu, diharapkan bagi pendidik menggunakan berbagai metode yang kreatif dan inovatif dalam membantu proses pembelajaran agar tujuan pembelajaran dapat tercapai dengan baik, selain itu tercipta suasana gembira dan tidak cepat membosankan bagi anak saat belajar.

Kata Kunci : anak usia dini, metode bercerita, perkembangan bahasa 
Jurnal PG-PAUD Trunojoyo : Jurnal Pendidikan dan Pembelajaran Anak Usia Dini, Volume 8, Nomor 2, Oktober 2021, hal 74-86, ISSN : 2528-3553 (online), ISSN: 2407-4454 (print)

\section{PENDAHULUAN}

Pendidikan anak usia dini sangat penting keberadaannya karena melalui pendidikan maka stimulasi yang tepat dapat dilakukan. Stimulasi yang dilakukan pada semua aspek perkembangan menentukan keberhasilan anak dalam melakukan tugas perkembangannya. Salah aspek yang penting distimulasi adalah aspek bahasa.

Bromley (Dhieni \& Lara, 2014) mendefinisikan bahasa sebagai sistem simbol yang teratur untuk mentransfer berbagai ide maupun informasi yang terdiri atas simbol-simbol visual maupun verbal. Bahasa juga menjadi alat komunikasi yang digunakan dalam menyampaikan ide atau gagasan, maksud atau himpunan kalimat yang mengandung arti (Nofrion, 2018). Perkembangan bahasa sebagai hasil interaksi anak dengan lingkungan dan juga kemampuan kognitif dan pengalaman bahasa (Piaget dalam Rizkiyana, 2019) yang bukan saja dipengaruhi oleh perkembangan neurologis tetapi juga oleh perkembangan biologisnya (Yamin dan Sanan dalam Muyassaroh, 2016).

Perkembangan bahasa sangat penting bagi anak usia dini karena dengan bahasa anak dapat berkomunikasi untuk menyampaikan pendapat maupun keinginannya kepada orang tua, guru, maupun teman sebayanya (Fitria, 2019). Perkembangan bahasa anak usia dini terbagi atas dua periode besar, yaitu: periode pralinguistik (0-1 tahun) dan linguistik (1-6 tahun). Tahap periode pralinguistik usia 0-3 bulan, bunyi yang dihasilkan oleh anak di dalam dan berasal dari tenggorokan dan pada usia 3-12 bulan, anak berbicara banyak memakai bibir dan langit-langit seperti ma, da, ba (Kurniati, 2017).

Peran bahasa sangat penting bagi anak usia dini, dimana melalui bahasa anak dapat berkomunikasi dengan orang lain dan menyampaikan apa yang anak ketahui. Namun fakta di lapangan perkembangan bahasa anak usia dini masih kurang. Salah satunya berdasarkan pengamatan penulis menjadi guru pendamping selama 2 bulan lebih di Pusat Tumbuh Kembang Anak (PTKA) Makassar Sulawesi Selatan, merupakan salah satu tempat penitipan anak. Berdasarkan hasil pengamatan penulis selama menjadi guru pendamping terdapat beberapa anak berkisar umur 3 sampai 5 tahun perkembangan bahasanya masih kurang yaitu perkembangan kosakata masih kurang, pengucapan kurang jelas dan masih merasa malu bertanya. Adapun hasil penelitian yang dilakukan oleh Aisyah Oktavia Siregar dan Nur Hazizah tentang Studi Kasus Keterlambatan Bicara Anak Usia 6 Tahun di Taman KanakKanak. Berdasarkan hasil dari pengamatan yang di dapatkan peneliti yaitu artikulasi anak dalam berbicara belum jelas, anak tidak bisa menyampaikan apa yang diinginkannya dan anak dalam perkembangan bicara belum berkembang sesuai tahapan umur anak yang semestinya (Siregar \& Nur Hazizah, 2019).

Selain itu adapun penelitian yang dilakukan oleh Nadia Intan Suradinata dan Ega Asnatasia Maharani tentang Pengaruh Berbicara Berbantuan Media Boneka Tangan terhadap Kemampuan Berbicara Anak. Hasil dari observasi dan wawancara yang didapatkan oleh peneliti yaitu anak ketika menyampaikan keinginan dan pikirinnya kepada guru masih terbata-bata dan guru masih susah memahami kalimat yang di ucapkan anak, beberapa anak masih mengulang kata seccara terusterusan ketika melakukan percakapan baik dengan guru maupun dengan teman sebayanya dan tidak jelas dalam mengucapkan huruf-huruf (Suradinata \& Ega, 2020). Permasalahan-permasalahan itu terjadi dikarenakan kurangnya dukungan dari metode dan media yang digunakan.

Ada berbagai macam bentuk metode pembelajaran yang dapat digunakan pada anak usia dini salah satunya adalah metode bercerita. Metode bercerita menjadi salah satu metode pengembangan bahasa yang dapat 
Jurnal PG-PAUD Trunojoyo : Jurnal Pendidikan dan Pembelajaran Anak Usia Dini, Volume 8, Nomor 2, Oktober 2021, hal 74-86, ISSN : 2528-3553 (online), ISSN: 2407-4454 (print)

mengembangkan beberapa aspek sesuai dengan tahap perkembangan anak (Madyawati, 2016). Berbagai hasil penelitian menunjukkan metode bercerita dapat meningkatkan kemampuan berbahasa anak (Ariska, (2018); Utami, (2014).

Bahkan sejak dulu metode bercerita banyak digunakan dalam pendidikan anak. Sebagaimana Imam al-Gaqazali (Ratnasari, 2017) mengatakan "Seorang anak hendaknya diajari Al-quran, hadis nabi, kisah perjalanan nabi dan kisah-kisah orang shaleh sehingga tertanam dalam diri anak". Hal tersebut sesuai pendapat Dimyati (2016) bahwa tujuan penggunaan metode bercerita salah satunya untuk menanamkan nilai-nilai budi pekerti.

Adapun kelebihan penggunaan metode bercerita diantaranya: (a) dapat diberlakukan pada jumlah peserta didik yang banyak, (b) adanya pemanfaatan waktu dengan efektif dan efisien, (c) pengaturan kelas dapat dilakukan lebih sederhana, (d) kelas mudah dikuasi guru, (e) tidak memerlukan lebih banyak biaya (Prihanjani, Wirya, \& Tirtayani, 2020).

Selain kelebihan, penggunaan metode bercerita juga memiliki beberapa kekurangan antara lain (a) Guru atau orangtua terkadang malu untuk berekspresi saat bercerita; (b) Terkadang anak jenuh dan tidak konsentrasi karena dalam bercerita tidak digunakan media atau alat peraga atau penyajian yang kurang menarik; (c) Anak kadang pasif menahan banyak hal yang ingin diketahui untuk ditanyakan ketika guru atau orangtua bercerita; (d) Karena lebih banyak mendegarkan, kadang membuat anak didik menjadi pasif; (e) Anak didik kurang distimulasi kreativitas dan kemampuan mengutarakan pendapatnya; (f) Tidak semua anak didik mampu memahami isi pokok cerita karena daya serap atau daya tangkap yang berbeda (Ratnasari, 2017).

Meskipun telah banyak dilakukan penelitian tentang perkembangan Bahasa anak melalui metode bercerita, namun pada artikel kali ini mencoba mengurai alasan dibalik kenapa metode bercerita dapat meningkatkan kemampuan bahasa anak. Berdasarkan uraian tersebut, maka tujuan dalam penelitian ini untuk mengetahui peran metode bercerita terhadap perkembangan bahasa anak usia dini.

\section{METODE}

Penelitian ini menggunakan jenis penelitian yang berupa studi kepustakaan (Library Research). Sumber bahan bacaan yang digunakan dalam penelitian kepustakaan bersumber dari penelitian orang lain yang sudah diterbitkan dalam bentuk buku, jurnal maupun dalam bentuk artikel yang bisa didapatkan di perpustakaan maupun di internet.

Teknik pengumpulan data yang digunakan oleh peneliti adalah menggunakan studi dokumentasi. Sumber dokumen yang dijadikan data yang digunakan sebanyak 11 artikel jurnal nasional yang sesuai isinya dengan fokus penelitian. Strategi penelusuran jurnal dilakukan dengan menelusuri setiap jurnal dengan kriteria metode bercerita, perkembangan bahasa, anak usia dini. Jurnal yang dipilih dan direview adalah jurnal terbitan tahun 2014-2020 yang dapat diakses dalam bentuk pdf dan merupakan penelitian berbahasa Indonesia dengan subjek anak usia dini. Berikut adalah diagram alur reviu jurnal: 
Jurnal PG-PAUD Trunojoyo : Jurnal Pendidikan dan Pembelajaran Anak Usia Dini, Volume 8, Nomor 2, Oktober 2021, hal 74-86, ISSN : 2528-3553 (online), ISSN: 2407-4454 (print)

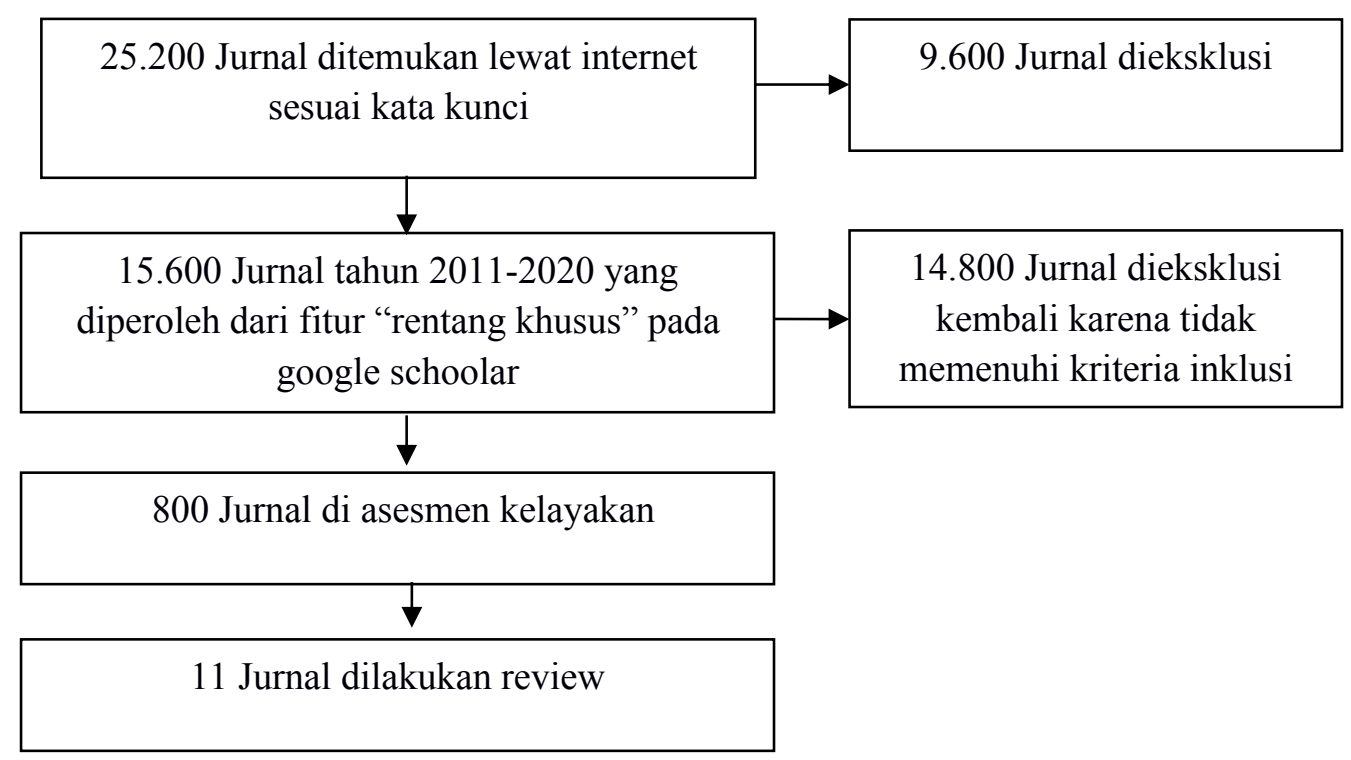

Gambar 1. Diagram Alur Jurnal yang direview

Teknik analisis data yang digunakan dalam penelitian ini menggunakan analisis deskriptif model Miles dan Huberman yang terdiri dari tiga langkah yaitu reduksi data, display data dan penarikan kesimpulan.

\section{HASIL DAN PEMBAHASAN}

Penelitian ini menggunakan studi kepustakaan (Library Research) yaitu sumber bahan bacaan yang digunakan bersumber dari penelitian orang lain yang sudah diterbitkan dalam bentuk buku, jurnal maupun dalam bentuk artikel. Usia subyek dari masing-masing 11 jurnal yang digunakan peneliti sebagai sumber bahan penelitian berkisar 3 sampai 6 tahun.

Berdasarkan penelitian yang telah dihasilkan dari para penelitian lainnya tentang peran metode bercerita terhadap perkembangan bahasa anak usia dini. Penelitian ini, fokus pada 11 jurnal yang telah direview yang sesuai dengan fokus penelitian dan akan dipaparkan melalui result ini, seperti penelitian yang dilakukan oleh Nur'Aini Fitria dalam penelitiannya menyatakan bahwa anak-anak sangat antusias dalam belajar dengan menggunakan metode bercerita. Metode bercerita dalam penelitian ini, menyajikan cerita yang menarik dengan berbagai media visual, seperti media laptop dan media buku. Penggunaan metode bercerita dengan beragam media membuat anak tidak bosan mengikuti kegiatan pembelajaran mendengarkan cerita. Metode bercerita membuat anak mampu berkomunikasi secara lisan, perbendaharaan kata anak meningkat dan mengenalkan simbol-simbol huruf kepada anak untuk persiapan membaca, menulis dan berhitung berkembang sangat baik (Fitria, 2019).

Selaras dengan penelitian Ni Made Sri Astuti Nugraha, A.A. Istri. N.M, Nyoman T. Dalam penelitiannya menyatakan bahwa kegiatan pembelajaran menggunakan metode bercerita dengan media gambar secara signifikan dapat meningkatkan kemampuan berbahasa dan sikap mandiri anak. Dalam penelitiannya, guru menyediakan media gambar yang berwarna-warni yang diambil dari bukubuku cerita dan guru memilih sendiri gambar yang akan disajikan kepada anak. Penelitian ini menunjukkan kemampuan anak mengungkapkan bahasa berkembang sangat baik, kemampuan anak menerima 
Jurnal PG-PAUD Trunojoyo : Jurnal Pendidikan dan Pembelajaran Anak Usia Dini, Volume 8, Nomor 2, Oktober 2021, hal 74-86, ISSN : 2528-3553 (online), ISSN: 2407-4454 (print)

bahasa berkembang sangat baik dan aspek keaksaraan anak berkembang sangat baik. Penelitian ini juga menjelaskan bahwa kegiatan bercerita dengan menggunakan media gambar menciptakan suasana belajar yang menyenangkan bagi anak, membantu daya ingat anak. Melalui mendengar dan melihat, anak memperoleh berbagai macam informasi tentang pengetahuan dunia, sikap, nilai yang ada dalam cerita, anak mampu memahami pesan yang terkandung dalam cerita kemudian dihayati dan diterapkan dalam kehidupan sehari-hari pesan moral yang ada dalam cerita (Nugraha, Marhaeni \& Tika, 2014).

Hal yang sama ditemukan oleh Sarayati bahwa metode bercerita dengan media gambar dapat meningkatkan kemampuan bahasa anak secara signifikan khususnya aspek kemampuan anak mengungkapkan bahasa, aspek kemampuan anak didalam menerima bahasa, dan aspek keaksaraan. Kegiatan pembelajaran dengan menggunakan metode bercerita dengan media gambar memberikan pengalaman belajar yang unik, melatih keberanian, dan membangkitkan semangat serta meningkatkan perkembangan kosakata. Metode bercerita dengan media gambar juga dapat meningkatkan sikap mandiri anak (Sarayati, 2018).

Penelitian selanjutya oleh Prihanjani, Wirya, dan Tirtayani (2020) dalam penelitiannya menunjukkan terdapat peningkatan terhadap keberhasilan belajar kemampuan bicara anak dengan menggunakan metode bercerita berbantuan media boneka tangan yang dilakukan secara terus menerus. Selain meningkatkan kemampuan bicara anak, mengubah posisi duduk juga dapat membantu konsentrasi dan fokus anak tetap terjaga selama proses pembelajaran (Prihanjani, Wirya, \& Tirtayani, 2020).

Hal yang sama ditemukan oleh Ayu Putri Nurjanah dan Gita Anggriani dalam penelitiannya bahwa penggunaan metode bercerita dapat meningkatkan kemampuan bicara anak. Kemampuan bicara anak meningkat yang ditandai dengan anak sudah berani menceritakan pengalaman dan identitas di depan temannya, mampu mengikuti kegiatan menceritakan namanama buah sangat baik dan menglafalkan doa-doa sehari- hari (Nurjanah \& Anggraini, 2020).

Berdasarkan uraian yang telah dipaparkan dapat ditarik kesimpulan bahwa penggunaan metode bercerita dapat meningkatkan kemampuan bicara anak. Selain dapat meningkatkan kemampuan bicara, metode bercerita juga dapat meningkatkan kepercayaan diri anak ketika tampil di depan teman-temannya serta meningkatkan aspek agama anak yaitu ketika anak mengucapkan atau melafalkan doa-doa sehari-hari.

Jika penelitian sebelumnya fokus menggunakan satu media, penelitian oleh Elya, Nadiroh, dan Nurani (2019) menggunakan metode bercerita dengan dua taraf yaitu media boneka tangan dan media power point dan variabel atribut adalah gaya belajar yang terdiri dari dua taraf yaitu auditory dan visual. Hasilnya menunjukkan anak yang diajarkan menggunakan metode bercerita dengan media boneka tangan yang memiliki gaya belajar auditory kemampuan berbicaranya lebih tinggi daripada anak yang memiliki gaya belajar visual. Anak yang memiliki gaya belajar auditory lebih tepat menggunakan metode bercerita dengan media boneka tangan. Sedangkan anak yang diajarkan menggunakan metode bercerita dengan media power point yang memiliki gaya belajar visual kemampuan berbicaranya lebih tinggi daripada anak yang memiliki gaya belajar auditory. Artinya untuk meningkatkan kemampuan berbicara anak, maka anak yang memiliki gaya belajar visual lebih tepat menggunakan metode bercerita dengan media power point. Oleh karena itu dapat disimpulkan bahwa metode bercerita dan 
Jurnal PG-PAUD Trunojoyo : Jurnal Pendidikan dan Pembelajaran Anak Usia Dini, Volume 8, Nomor 2, Oktober 2021, hal 74-86, ISSN : 2528-3553 (online), ISSN: 2407-4454 (print)

gaya belajar berpengaruh terhadap kemampuan berbicara anak.

Anak lebih tertarik dan senang mendengarkan cerita dengan media boneka tangan. Selain itu boneka tangan dapat diperagakan secara langsung oleh anak. Boneka tangan dapat digunakan dalam memerankan suatu tokoh dalam cerita. Selain dapat digunakan secara langsung boneka tangan memberikan kesenangan tersendiri, membangun kepercayaan diri anak saat tampil bercerita di depan kelas dan boneka tangan ini dapat membantu anak mengingat cerita ketika anak bercerita (Elya, Nadiroh, \& Nurani, 2019).

Rahmat dan Mamonto (2016) dalam penelitiannya menunjukkan terdapat peningkatan secara signifikan kemampuan menyimak anak menggunakan metode bercerita. Kemampuan menyimak anak semakin meningkat setelah diterapkan metode bercerita dibandingkan tidak menggunakan metode bercerita. Kemampuan menyimak anak merupakan salah satu aspek perkembangan bahasa, kemampuan menyimak dapat dijadikan dasar belajar dalam bahasa tulis, sehingga kemampuan menyimak sangat penting untuk dikembangkan. (Rahmat \& Mamonto, 2016).

Hal yang sama ditemukan oleh Rahmatillah, Luthfi, dan Fauziddin (2018) dalam penelitiannya memperoleh hasil bahwa kemampuan menyimak anak mengalami kemajuan. Penggunaan metode bercerita lebih efektif digunakan dalam proses pembelajaran dibandingkan tanpa menggunakan metode bercerita (Rahmatillah, Luthfi, \& Fauziddin, 2018).

$$
\text { Lilis Darmila (2018) dalam }
$$
penelitiannya menunjukkan metode bercerita berpengaruh terhadap pekembangan kosakata anak. Terjadi peningkatan hasil perkembangan kosakata anak setelah diberikan perlakuan yang dibuktikan dengan rata-rata perkembangan kosakata anak yang diajarkan dengan metode bercerita lebih baik dibandingkan dengan metode tanya jawab. Penelitian ini juga menemukan bahwa penggunaan metode bercerita dengan berbagai tema yang beragam akan mengembangkan kemampuan daya ingat anak. Selain mengembangkan perkembangan kosakata juga mengembangkan bahasa lisan. Bahasa lisan mendukung anak-anak untuk belajar membaca, memahami pengetahuan dunia, dan menjadikan sosial-emosi baik. Metode bercerita juga melatih daya imajinasi anak, menanamkan nilai-nilai moral dan melatih anak untuk peka terhadap lingkungan sekitarnya (Darmila, 2018).

Rika Andriyani, Masrul, Moh Fauziddin dalam penelitianya menunjukkan cerita yang dikemas dan disajikan dengan menarik akan membuat anak tertarik untuk mendengarkan kelanjutan dari cerita yang dibacakan, sehingga akan terjadi umpan balik antara guru dan peserta didik. Penelitian ini juga menjelaskan kemampuan kosakata anak dapat berkembang dengan bantuan orang dewasa dengan menerapkan metode dan media yang tepat, semakin banyak kosakata yang diperoleh anak maka akan semakin beragam kalimat yang dapat dikuasai oleh anak sehingga anak dapat mengungkapkan kosakata baru yang diperoleh dari teman maupun orangtuanya (Andriyani, Masrul, \& Fauziddin 2018).

Berdasarkan hasil pembahasan yang telah di uraikan oleh peneliti, berikut peneliti memaparkan tabel aspek perkembangan bahasa anak usia dini yang mengalami peningkatan sesudah menggunakan metode bercerita. dari 11 jurnal yang telah dikaji. 
Jurnal PG-PAUD Trunojoyo : Jurnal Pendidikan dan Pembelajaran Anak Usia Dini, Volume 8, Nomor 2, Oktober 2021, hal 74-86, ISSN : 2528-3553 (online), ISSN: 2407-4454 (print)

Tabel 1. Aspek Perkembangan Bahasa

\begin{tabular}{|c|c|c|}
\hline \multirow[t]{2}{*}{ NO. } & \multicolumn{2}{|c|}{ ASPEK PERKEMBANGAN BAHASA ANAK USIA DINI } \\
\hline & $\begin{array}{c}\text { Sebelum diberikan metode } \\
\text { bercerita }\end{array}$ & Sesudah diberikan metode bercerita \\
\hline 1. & $\begin{array}{l}\text { Perkembangan bahasa anak yaitu } \\
\text { kemampuan berbicara anak } \\
\text { belum berkembang secara } \\
\text { optimal. }\end{array}$ & $\begin{array}{l}\text { Kemampuan berbicara anak mengalami peningkatan setelah } \\
\text { diberikan metode bercerita yaitu: } \\
\text { 1. Kemampuan berbicara dan berkomunikasi anak } \\
\text { mengalami peningkatan. Hal itu terlihat ketika anak } \\
\text { sangat antusias mengikuti kegiatan berbicara setelah } \\
\text { guru menunjukkan media gambar dan anak-anak tidak } \\
\text { sabar menunggu giliran untuk berbicara. } \\
\text { 2. Aspek kemampuan anak menerima bahasa. } \\
\text { 3. Aspek keaksaraan ( baca tulis). } \\
\text { 4. Anak mampu menirukan suara/ tokoh dalam cerita. } \\
\text { 5. Anak mampu bertanya sesuai tema cerita. } \\
\text { 6. Anak mampu menyatakan pikirannya sesuai isi cerita. } \\
\text { 7. Anak mampu bercerita menggunakan media yang } \\
\text { disediakan. } \\
\text { 8. Anak mampu menceritakan pengalaman/ kejadian secara } \\
\text { sederhana. } \\
\text { 9. Anak berani menceritakan pengalaman dan identittas di } \\
\text { depan teman-temannya. } \\
\text { 10. Anak mampu melafalkan doa sehari-hari dan surat-surat } \\
\text { pendek. } \\
\text { 11. Anak mampu menceritakan kembali cerita sesuai isi } \\
\text { cerita sambil memperagakannya dengan benar. }\end{array}$ \\
\hline 2. & $\begin{array}{l}\text { Kemampuan menyimak anak } \\
\text { belum berkembang } \\
\text { optimal }\end{array}$ & $\begin{array}{l}\text { Kemampuan menyimak anak mengalami peningkatan setelah } \\
\text { diberikan metode bercerita yaitu: } \\
\text { 1. anak menyebutkan sifat-sifat tokoh yang ada pada cerita } \\
\text { yang di dengar. } \\
\text { 2. Anak memahami perkataan guru. } \\
\text { 3. Anak mampu menyebutkan judul cerita. } \\
\text { 4. Anak menyebutkan tokoh-tokoh dalam cerita. } \\
\text { 5. Anak mampu menjawab pertanyaan dengan benar sesuai } \\
\text { isi cerita. }\end{array}$ \\
\hline 3. & \begin{tabular}{llr}
\multicolumn{2}{l}{ Kemampuan kosakata } & anak \\
belum & berkembang & secara \\
optimal. & & \\
\end{tabular} & $\begin{array}{l}\text { Kemampuan kosakata anak mengalami peningkatan setelah } \\
\text { diberikan metode bercerita yaitu: } \\
\text { 1. Anak mampu menyebutkan warna dengan tepat. } \\
\text { 2. Anak mampu menjawab pertanyaan dari guru. } \\
\text { 3. Anak mampu menjawab pertanyaan dengan benar sesuai } \\
\text { isi cerita. } \\
\text { 4. Anak mampu menceritakan nama-nama buah. } \\
\text { 5. Aspek kemampuan anak mengungkapkan bahasa. } \\
\text { 6. Anak mampu membuat kalimat sederhana. }\end{array}$ \\
\hline
\end{tabular}

Selain memaparkan hasil peningkatan kemampuan bahasa anak usia dini sesudah menggunakan metode bercerita. Peneliti juga memaparkan kerangka hasil temuan-temuan mengenai peran metode bercerita dari 11 jurnal yang telah dikaji sebagai berikut. 
Jurnal PG-PAUD Trunojoyo : Jurnal Pendidikan dan Pembelajaran Anak Usia Dini, Volume 8, Nomor 2, Oktober 2021, hal 74-86, ISSN : 2528-3553 (online), ISSN: 2407-4454 (print)

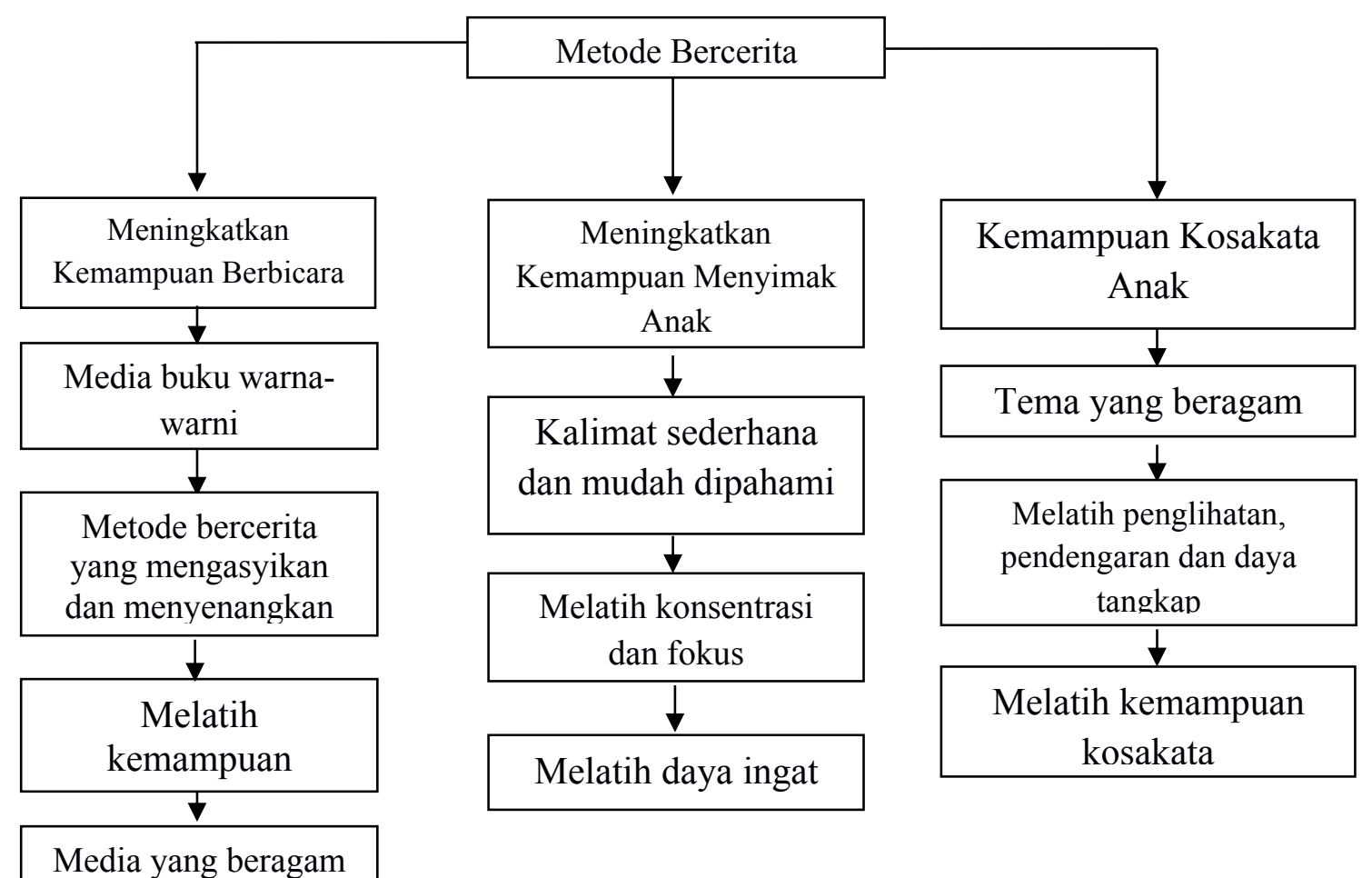

Gambar 2. Kerangka Hasil Penelitian

Berdasarkan hasil pemaparan sebelumnya, maka dapat diperoleh gambaran bahwa peran metode bercerita dalam meningkatkan perkembangan bahasa anak usia dini dapat dijabarkan sebagai berikut:

\section{Metode Bercerita dapat \\ Meningkatkan \\ Berbicara Anak \\ Kemampuan \\ Penelitian ini menemukan temuan} bahwa metode bercerita dapat mengembangkan kemampuan berbicara anak. Alasannya didukung oleh beberapa pendapat dari ahli atau hasil penelitian karena dalam bercerita terdapat Bahasa yang menggunakan artikulasi dan memuat keterampilan intelektual motorik (Hurlock dalam Usman (2019). Melalui bercerita, kemampuan bahasa anak mengalami peningkatan yang ditunjukkan dengan anak mampu berkomunikasi secara lisan, perbendaharaan kata meningkat dan dapat mengenalkan simbol-simbol huruf yang dapat digunakan untuk persiapan membaca, menulis dan menghitung (Fitria, 2019). Kemampuan bercerita bukan hanya meningkatkan Bahasa anak tapi juga dengan kalimat yang disampaikan dapat menggambarkan perasaan (Nurjanah \& Anggraini, 2020).

Peningkatkan

kemampuan berbicara tersebut terjadi dikarenakan metode bercerita menyajikan cerita dengan media yang beragam, seperti buku yang berwarna-warni, boneka tangan, dan power point. Sebagaimana dalam penelitian Prihanjani, Wirya, \& Tirtayani (2020) mengemukakan metode bercerita dapat meningkatkan kemampuan bicara anak karena menggunakan boneka tangan. Selain itu Hurlock juga menyatakan bahwa salah satu faktor yang dapat memperbaiki pembicaraan anak adalah dengan menggunakan media radio atau televisi (Usman, 2019).

Selain penggunaan media yang menarik, ternyata mengubah posisi duduk anak juga mendukung kemampuan anak dalam bercerita. 
Jurnal PG-PAUD Trunojoyo : Jurnal Pendidikan dan Pembelajaran Anak Usia Dini, Volume 8, Nomor 2, Oktober 2021, hal 74-86, ISSN : 2528-3553 (online), ISSN: 2407-4454 (print)

Sebagaimana dalam penelitian Prihanjani, Wirya, dan Tirtayani (2020) menyatakan bahwa mengubah posisi duduk anak dapat meningkatkan kemampuan bicara anak. Anak yang awalnya tidak mau fokus mendengarkan cerita setelah diubah posisi duduknya anak bisa fokus dan konsentrasi mendengarkan cerita yang dibacakan oleh guru. Mengubah strategi posisi duduk anak. Menurut Elya, Nadiroh, dan Nurani (2019) dalam penelitiannya menyatakan bahwa, anak yang memiliki gaya belajar auditori lebih tepat menggunakan metode bercerita dengan media boneka tangan sedangkan anak yang memiliki gaya belajar visual lebih tepat menggunakan metode bercerita dengan media power point.

Anak yang memiliki gaya belajar kinestetik lebih tepat menggunakan metode bercerita dengan media audiovisual seperti, film dan vidio. Sebagaimana menurut Zagoto, Yarni, dan Dakhi (2019) dalam penelitiannya menyatakan bahwa ciri-ciri anak kinestetik yaitu: menyentuh/memegang/ meraba untuk memperoleh perhatian orang, berbicara dengan pelan, merespon perhatia fisik, berdiri dekat dengan lawan bicara, selalu berorientasi pada fisik dan banyak bergerak, memiliki pertumbuhan dan perkembangan awal otot-otot yang besar, menghafal atau mengingat dengan cara berjalan atau melihat, menunjuk bacaan ketika sedang membaca, banyak menggunakan isyarat tubuh, dan tidak dapat duduk diam untuk waktu lama.

\section{Metode bercerita dapat meningkatkan menyimak anak kemampuan}

Pada penelitian ini ditemukan metode bercerita dapat meningkatkan kemampuan menyimak anak dengan prasyarat kalimat yang disampaikan sesuai dengan standar perkembangan anak sehingga anak mudah memahaminya. Selain itu kemampuan Bahasa dapat ditingkatkan dengan menyajikan cerita yang ditandai dengan melatih konsentrasi dan fokus serta melatih daya ingat.

Bagian yang paling penting dari kemampuan Bahasa adalah kemampuan menyimak karena pada dasarnya dari kemampuan menyimak inilah menjadi indicator dapat diketahui kemampuan Bahasa anak. Dalam kegiatan menyimak anak dapat mendengarkan lambang-lambang bahasa lisan dengan penuh perhatian, pemahaman, apresiasi, serta interprestasi untuk memperoleh informasi, menangkap maksud dari pesan dan memahami makna ucapan yang disampaikan oleh pembaca (Rahmatillah, Luthfi, \& Fauziddin (2018).

Pemberikan metode bercerita seperti yang dilakukan oleh peneliti merupakan salah satu upaya untuk melatih anak. Menurut Rahmat dan Mamonto, (2016) kemampuan menyimak perlu dilatih sejak dini karena tidak mudah terbentuk begitu saja agar anak terbiasa memahami maksud atau pesan yang diucapkan oleh pencerita.

Cara mengembangkan kemampuan menyimak anak dengan menggunakan metode dan media yang tepat dan sesuai dengan kebutuhan anak serta mempertimbangkan kematangan pertumbuhan dan perkembangan anak. Salah satunya dengan menggunakan metode bercerita dengan media buku yang menarik sesuai dengan tema pembelajaran seperti tema binatang. Guru menyebutkan dan menceritakan secara singkat jenis-jenis binatang, binatang dikelompokkan berdasarkan makanannya, kemudian setelah selesai cerita guru memberikan kesempatan kepada anak untuk menceritakan ulang 
Jurnal PG-PAUD Trunojoyo : Jurnal Pendidikan dan Pembelajaran Anak Usia Dini, Volume 8, Nomor 2, Oktober 2021, hal 74-86, ISSN : 2528-3553 (online), ISSN: 2407-4454 (print)

apa yang ditangkap serta menanyakan perasaan suasana hati dari cerita yang diceritakan, melalui pemberian kesempatan tersebut guru dapat mengetahui sejauh mana peserta didik memahami terhadap kemampuan menyimaknya.

Adapun kegiatan lain yang dapat meningkatkan kemampuan menyimak selain membacakan cerita yaitu: membuat teka-teki dan mengajak anak untuk menebak berbagai jawaban, mengajak anak untuk membuat teka teki sendiri lalu membacakan kepada temannya, mengajak anak menonton televisi atau vidio, lalu menanyakan kesan cerita yang di nonton anak. Oleh karena itu metode bercerita dapat dijadikan acuan dalam meningkatkan kemampuan menyimak anak.

\section{Metode Bercerita dapat Meningkatkan Kemampuan Kosakata Anak}

Temuan ketiga penelitian ini bahwa metode bercerita selain dapat meningkatkan aspek kemampuan menyimak juga dapat meningkatkan kemampuan kosakata anak. Menurut Darmila (2018) penggunaan metode bercerita dengan berbagai tema yang beragam akan mengembangkan kemampuan daya ingat anak untuk mengingat tiap kata yang diucapkan dari cerita yang disajikan dan melatih anak untuk memahami maksud dari tiap kata yang diucapkan.

Penggunaan metode bercerita dengan tema beragam dan menceritakan cerita secara berulang-ulang akan membantu memperkaya kosakata pengetahuan anak dan meningkatkan kemampuan kosakata anak. Sebagaimana dikemukakan oleh Owens (Usman, 2019) bahwa anak usia 4-5 tahun dapat memperkaya kosakatanya melalui pengulangan. Anak sering mengulang kosakata yang baru meskipun belum memahami artinya
Dalam mengembangkan kemampuan kosakata anak, guru perlu melatih anak untuk belajar mengaitkan kata dengan bunyi, dimana ada beberapa kata yang sama tapi memiliki makna yang lebih dari satu. Hal itu seperti yang dikemukakan oleh Hurlock bahwa membangun kosakata anak dimulai dengan belajar mengaitkan arti dengan bunyi. Hal itu terjadi karena banyak kata yang memiliki arti lebih dari satu dan sebagian kata bunyinya hampir sama, tetapi memiliki arti yang berbeda (Muyassaroh, 2016). Arti dari mengkaitkan kata dengan bunyi yaitu belajar membaca dengan menunjukkan bunyi masing-masing huruf, kemudian menggabungkan dengan huruf lain sehingga terdengar bunyi seluruh kata, contohnya kata Allah, A...A...A dan kata cerdas Ce...Ce...Ce meminta anak untuk mengulangi kata tersebut sebanyak tiga kali sambil bernyayi dengan melihat media gambar kata Allah dan gambar yang jelas ditampilkan, setelah dilakukan 3 kali kemudian meminta anak untuk menunjukkan huruf abjad dan menyebutkannya (Syakir, 2020).

Perkembangan kosakata mengalami peningkatan tidak terlepas dari stimulasi yang diberikan oleh guru dan semangat anak untuk mau mengikuti proses pembelajaran dengan mengikuti aturan yang sudah disepakatin dengan guru. Stimulasi yang dapat diberikan oleh guru dalam mengembangkan kemampuan kosakata anak dapat dilakukan menyajikan cerita dengan berbagai tema seperti hari pertama menyajikan cerita dengan tema kebutuhan dengan media buku gambar makanan 4 sehat 5 sempurna/pedoman gizi seimbang yaitu nasi, ikan, sayur, buah dan susu, hari berikutnya menyajikan cerita makanan jajanan seperti sate, soto, sosis bakar, somay. Kemudian selanjutnya menyajikan cerita yang berkaitan dengan kebutuhan 
Jurnal PG-PAUD Trunojoyo : Jurnal Pendidikan dan Pembelajaran Anak Usia Dini, Volume 8, Nomor 2, Oktober 2021, hal 74-86, ISSN : 2528-3553 (online), ISSN: 2407-4454 (print)

yang melekat pada diri anak seperti celana, rok, sepatu, sandal, baju, dan topi. Menyajikan cerita dengan beragam tema akan membantu meningkatkan kemampuan kosakata anak.

\section{SIMPULAN}

Berdasarkan hasil dari penelitian yang telah diuraikan sebelumnya dapat ditarik kesimpulan bahwa metode bercerita mempunyai peran penting terhadap perkembangan bahasa anak usia dini yaitu kemampuan bicara, kemampuan menyimak dan kemampuan kosakata anak. Metode bercerita dapat meningkatkan kemampuan bicara bagi anak. Hal itu tidak terlepas dari kelebihan-kelebihan yang dimiliki oleh metode cerita tersebut, seperti media buku yang warna-warni, menyenangkan, dan mengasyikan serta melatih kemampuan berbicara dan keberanian anak tampil bercerita di depan kelas. Metode bercerita menarik dari segi penggunaannya, yaitu media boneka tangan, media power point, dan media audiovisual sehingga membuat pembelajaran menjadi tidak membosankan.

Metode bercerita juga dapat meningkatkan kemampuan menyimak anak. Metode ini menarik perhatian anak, karena tampilan cerita yang disajikan menggunakan bahasa yang sederhana dan mudah dipahami oleh anak. Selain itu, metode bercerita dapat meningkatkan kemampuan kosakata anak, melalui cerita yang disuguhkan dengan menggunakan tema yang beragam membuat anak mengetahui berbagai macam kata baru dan anak dapat membuat kalimat sederhana maupun kompleks dari kata yang diketahuinya.

Penelitian ini memiliki keterbatasan karena belum menguraikan keterbatasan dalam penggunaan metode bercerita karena pada dasarnya anak usia dini memiliki keunikan tersendiri yang potensial memiliki kemampuan yang berbeda antara auditori, visual dan kinestetik. Sehingga yang menjadi rekomendasi sebagai implikasi penelitian ini bahwa untuk peneliti berikutnya agar meneliti metode bercerita terhadap kemampuan Bahasa anak berdasarkan gaya belajar anak.

\section{DAFTAR PUSTAKA}

Andriyani, R., Masrul, M., \& Fauziddin, M. (2018). Pengaruh Metode Becerita Terhadap Kemampuan Kosakata Anak Usia Dini. Aulad: Journal on Early Childhood, 1(1), 18-27.

https://doi.org/10.31004/aulad.vli 1.3

Ariska, T. (2018). Pengaruh Metode Bercerita Terhadap Kemampuan Berbahasa Anak Di PAUD Sahabat Desa Padang Pelasan Kecamatan Air Periuk Kabupaten Seluma (Skripsi). Institut Agama Islam Negeri Bengkulu. Retrieved from

http://riset.unisma.ac.id/index.php/ thufuli/article/download/4915/447 7

Darmila, L. (2018). Pengaruh Metode Bercerita Terhadap Perkembangan Kosakatta Anak Usia 5-6 Tahun di RA Hajjah Siti Syarifah Kecamatan Medan Tembung. Jurnal Raudhah, 6(1), 2-8. Retrieved from http://jurnaltarbiyah.uinsu.ac.id/in dex.php/raudhah/article/view/276

Dhieni, N., \& Lara, F. (2014). Hakikat Perkembangan Bahasa Anak. Jakarta: Universitas Terbuka.

Dimyati, J. (2016). Pembelajaran Terpadu untuk Taman KanakKanak/Raudatul Athfal dan Sekolah Dasar. Jakarta: Prenadamedia Group.

Elya, M. H., Nadiroh, N., \& Nurani, Y. (2019). Pengaruh Metode Bercerita dan Gaya Belajar Terhadap Kemampuan Berbicara Anak Usia Dini. Jurnal Obsesi: 
Jurnal PG-PAUD Trunojoyo : Jurnal Pendidikan dan Pembelajaran Anak Usia Dini, Volume 8, Nomor 2, Oktober 2021, hal 74-86, ISSN : 2528-3553 (online), ISSN: 2407-4454 (print)

Jurnal Pendidikan Anak Usia Dini, 4(1), 302-315. https://doi.org/10.31004/obsesi.v4i 1.326

Fitria, N. 'Aini. (2019). Penerapan Metode Bercerita untuk Meningkatkan Kemampuan Bahasa Anak Kelompok A RA Muslimat NU 26 Malang. Jurnal Dewantara, 1(1), 7-13. Retrieved from http://riset.unisma.ac.id/index.php/ $\mathrm{jd} /$ article/view/1821

Kurniati, E. (2017). Perkembangan Bahasa Pada Anak dalam Psikologi serta Implikasinya dalam Pembelajaran. Jurnal Ilmiah Universitas Batanghari Jambi, 17(3), 47-56. https://doi.org/10.33087/jiubj.v17i 3.401

Madyawati, L. (2016). Strategi Pengembangan Bahasa pada Anak. Jakarta: Kencana.

Muyassaroh, A. R. (2016). Pengaruh Metode Bercerita terhadap Kemampuan Kosakata Dasar Anak Usia 4-5 Tahun di Ra Muslimat Banyumas Kabupaten Pringsewu Tahun Ajaran 2015/2016 (Skripsi). Universitas Lampung. Retrieved from http://digilib.unila.ac.id/22845/3/S KRIPSI TANPA BAB PEMBAHASAN.pdf

Nofrion. (2018). Komunikasi Pendidikan Penerapan Teori dan Konsep Komunikasi dalam Pembelajaran. Jakarta: Prenadamedia Group.

Nugraha, N. M. S. A., Marhaeni, A. A. I. N., \& Tika, N. (2014). Penggunaan Metode Bercerita dengan Media Gambar dalam Upaya Meningkatkan Kemampuan Berbahasa dan Sikap Mandiri Anak Kelompok A Tk Negeri Pembina Bangli Tahun Ajaran 2012/2013. Ganesha University of Education.

https://media.neliti.com/media/pub
lications/122568-ID-none.pdf

Nurjanah, A. P., \& Anggraini, G. (2020). Metode Bercerita untuk Meningkatkan Kemampuan Berbicara Pada Anak Usia 5-6 Tahun. Jurnal Ilmiah Potensia, 5(1), $\quad 1-7$. https://doi.org/10.33369/jip.5.1.17

Prihanjani, N. L., Wirya, I. N., \& Tirtayani, L. A. (2020). Metode Bercerita untuk Meningkatkan Kemampuan Berbicara Pada Anak Usia 5-6 Tahun. Jurnal Ilmiah Potensia, 5(1), 1-7. Retrieved from https://ejournal.undiksha.ac.id/ind ex.php/JJPAUD/article/download/ 8822/\%095709

Rahmat, A., \& Mamonto, E. (2016). Pengaruh Metode Bercerita Terhadap Kemampuan Menyimak Anak Usia 4-5 Tahun di Tk Negeri Pembina Ki Hadjar Dewantoro Kota Selatan Gorontalo. Journal of Nonformal Education and Community Empowerment, 5(1).

Rahmatillah, R., Luthfi, A., \& Fauziddin, M. (2018). Pengaruh Metode Bercerita Terhadap Kemampuan Menyimak Pada Anak Usia Dini. Aulad: Journal on Early Childhood, 1(1), 39-51. https://doi.org/10.31004/aulad.v1i 1.5

Ratnasari, S. (2017). Penerapan Metode Bercerita terhadap Perkembangan Sosial Emosional Anak di PAUD Sekar Wangi Kedaton Bandar Lampung (Skripsi). Universitas Islam Negeri Raden Intan. Retrieved from http://repository.radenintan.ac.id/8 99/1/SEPTIA.pdf

Rizkiyana, M. (2019). Meningkatkan Perkembangan Bahasa Anak Usia Dini Melalui Media Kartu Bergambar Kelompok A Di TK Aisyiah Bustanul Athfal Wates Gadingrejo Pringsewu (Skripsi). 
Jurnal PG-PAUD Trunojoyo : Jurnal Pendidikan dan Pembelajaran Anak Usia Dini, Volume 8, Nomor 2, Oktober 2021, hal 74-86, ISSN : 2528-3553 (online), ISSN: 2407-4454 (print)

Universitas Islam Negeri Raden Intan Lampung. Retrieved from http://library1.nida.ac.th/termpaper 6/sd/2554/19755.pdf

Sarayati. (2018). Penggunaan Metode Bercerita dengan Media Gambar dalam Upaya Meningkatkan Kemampuan Berbahasa dan Sikap Mandiri Anak TK B Dewi Sartika Sintang. Dunia Anak: Jurnal Pendidikan Anak Usia Dini, 1(2), 45-55.

https://doi.org/10.31932/jpaud.v1i 2.387

Syakir, A. (2020). Implementasi Metode Jolly Phones Bermuatan Nilai Islami untuk Pengenalan Huruf dan Kemampuan Melafalkan Fenom Bagi Anak Usia Dini. Jurnal Bahasa, Sastra Dan Pembelajarannya, 10(1), 59-67. Retrieved from https://ppjp.ulm.ac.id/journal/inde x.php/jbsp/article/view/8396

Siregar, A. S \& Nur, H. (2019). Studi Kasus Keterampilan Bicara Anak Usia 6 Tahun di Taman KanakKanak. Aulad: Journal on Early Childhood, 2(2), 22-27. https://aulad.org/index.php/aulad/a rticle/download/31/18.

Suradinata, N. I.., \& Ega, A. M. (2020). Pengaruh Bercerita Berbantuan
Media Boneka Tangan terhadap Kemampuan Berbicara Anak. Journal for Education Rresearch, $1(1)$, 28-37. https://jer.or.id/index.php/jer/articl e/dowload/4/3.

Usman, M. (2019). Perkembangan Bahasa dalam Bermain dan Permainan (untuk Pendidikan Anak Usia Dini). Yogyakarta: CV Budi Utama.

Utami, S. W. (2014). Pengaruh Metode Bercerita dengan Gambar Terhadap Perkembangan Bahasa Anak Usia 3-5 Tahun di Paud Sariharjo Ngaglik Sleman (Skripsi). STIKES'Aisyiyah Yogyakarta. Retrieved from http://digilib.unisayogya.ac.id/455/ 1/NASKAH PUBLIKASI SEP\%09TYANI WINDI UTAMI.pdf

Zagoto, M. M., Yarni, N., \& Dakhi, O. (2019). Perbedaan Individu dari Gaya Belajarnya serta Implikasinya dalam Pembelajaran. Jurnal Reviuw Pendidikan Dan Pengajaran, 2(2), 259-265. Retrieved from https://journal.universitaspahlawan. ac.id/index.php/jrpp/article/view/4 81 